\title{
PERILAKU KOMUNIKASI ANTARA GURU DENGAN SISWA BROKEN HOME
}

\author{
Emilsyah Nur \\ Balai Besar Pengkajian dan Pengembangan Komunikasi dan Informatika (BBPPKI) Makassar \\ JL. Prof. Dr. Basalamah II, No. 25, Makassar, Sulawesi Selatan, Indonesia \\ No. Telp./HP: 085322926069 \\ E-mail: emilsyah.nur@gmail.com
}

Naskah diterima tanggal 26 Juli 2017, direvisi tanggal 30 Oktober 201, disetujui tanggal 7 November 2017

\section{COMMUNICATION BEHAVIOUR BETWEEN TEACHERS AND BROKEN HOME STUDENTS}

\begin{abstract}
Communication behavior that occurs between parents and children about learning achievement is considered not effective. The intensity of interpersonal communication between parents and children tends to decrease, making children closed about their learning achievement. The aim of this study is to determine the communication behavior between teachers and students who experience broken home. This qualitative research uses several informants as resource persons to answer the problem about public opinion toward interpersonal communication in overcoming the broken home problem in children. The result of the research shows that the communication behavior of broken home students in the school has not been effective due to the low intensity of communication between parents and children so that children are not open to their parents about learning achievement and inequality between children and parents. Then, this communication behavior affects the behavior of children in school. Parents who are unable to spare the time between work and attention to the child at home have an impact on the effectiveness of communication between them. Parental ignorance keeps children away and not open to their parents. It brings the students closed to the teacher because of the students' fear and shame in telling their problems.
\end{abstract}

Keywords: behavior, communication, teachers, students, broken home.

\begin{abstract}
Abstrak. Perilaku komunikasi yang terjadi antara orangtua dan anak mengenai prestasi belajar belum sepenuhnya efektif. Dikarenakan kurangnya intensitas komunikasi interpersonal orangtua dan anak, sehingga anak enggan terbuka mengenai prestasi belajar. Tujuan penelitian ini adalah untuk mengetahui perilaku komunikasi antar guru dengan siswa yang mengalami broken home. Penelitian kualitatif ini menggunakan beberapa informan sebagai narasumber untuk menjawab permasalahan tentang opini publik terhadap komunikasi interpersonal dalam mengatasi permasalahan broken home pada anak. Hasil penelitian menunjukkan bahwa perilaku komunikasi siswa broken home di sekolah belum sepenuhnya efektif disebabkan oleh rendahnya intensitas komunikasi antara orangtua dan anak sehingga anak enggan untuk terbuka kepada orangtuanya mengenai prestasi belajar serta kurangnya kesetaraan antara anak dan orangtua. Selain itu, perilaku komunikasi juga sangat berpengaruh terhadap perilaku anak di sekolah. Orangtua yang tidak mampu membagi waktu antara pekerjaan dan perhatian kepada anak di rumah berdampak pada efektivitas komunikasi antara mereka. Ketidakpedulian yang ditunjukkan orangtua membuat anak menjauhkan diri dan tidak terbuka kepada orangtua, sehingga sikap tertutup siswa terhadap guru disebabkan oleh adanya rasa takut dan rasa malu siswa dalam manceritakan masalah yang mereka hadapi.
\end{abstract}

Kata kunci: perilaku, komunikasi, guru, siswa, broken home. 


\section{PENDAHULUAN}

Manusia sudah melakukan komunikasi sejak ia dilahirkan. Manusia melakukan proses komunikasi dengan lawan bicaranya baik di lingkungan masyarakat, tempat kerja, sekolah, maupun organisasi. Manusia melakukan komunikasi di manapun mereka berada, bahkan ketika mereka sedang sendiri kerapkali seseorang berkomunikasi dengan dirinya sendiri.

Namun, di antara lingkungan yang ada, keluargalah yang sangat memengaruhi dan dan berperan bagi kehidupan seseorang dikarenakan intensitas dan frekuensinya yang cenderung rutin dan tetap. Keluarga berasal dari bahasa Sansekerta yang terdiri dari kata "kula" dan "warga" yaitu "kulawarga" yang berarti anggota atau kelompok kerabat (Rahmadi, 2006).

Dewasa ini adanya perkembangan ilmu pengetahuan dan teknologi menyebabkan manusia cenderung memilih kehidupan yang serba canggih dan lebih banyak meniru perkembangan melalui ilmu pengetahuan dan teknologi. Adanya konten-konten yang ditampilkan di internet menyebabkan anakanak banyak meniru perilaku-perilaku yang kurang baik sehigga menyebabkan mereka menggunakan pikiran yang diadopsi dari teknologi yang ada.

Salah satu dampak yang dihasilkan adalah kurang terjalinnya komunikasi antara anak dan orangtua. Anak sibuk dengan kehidupan mereka sendiri dan orangtua sibuk juga dengan urusan sendiri, hal ini menyebabkan komunikasi antara anak dan orangtua kurang terjalin dengan baik.

Problem yang muncul sekarang bagaimana peran sekolah atau guru untuk menjalin komunikasi antara anak-anak yang memiliki orangtua yang sibuk dengan urusannya sendiri atau sering diistilahkan dengan broken home.

Peran guru sangat penting untuk membangun komunikasi yang lebih baik dengan siswa. Karena jika hal ini kurang mendapat perhatian dari pihak guru, maka siswa tersebut cenderung menutup diri sehingga akan berpengaruh terhadap kondisi psikologi siswa yang broken home. Sekarang ini bisa dilihat, anak yang broken home jatuh ke dalam pergaulan-pergaulaan yang sangat merugikan masa depan mereka seperti narkoba, pencurian, dan kejahatan lainnya. Kurang terbangunnya komunikasi yang baik antara anak dan orangtua berpengaruh terhadap perkembangan proses belajar mengajar anak di sekolah. Oleh karena itu, diperlukan adanya komunikasi untuk membangun komunikasi yang harmonis. Keluarga yang harmonis antara anggotanya sudah pasti memiliki komunikasi yang efektif.

Teknik komunikasi yang baik akan terjadi apabila semua anggota keluarganya memiliki rasa empati dan saling terbuka. Anak yang berasal dari keluarga harmonis akan mengidolakan dan merasa bangga pada orangtuanya. Berbeda sekali dengan anakanak yang berada atau hidup di dalam keluarga yang tidak harmonis (broken home), mereka cenderung menutup diri dan tidak banyak membahas keluarganya karena merasa malu.

Informan atau narasumber dalam penelitian ini adalah remaja usia SMA di mana mereka sedang berada pada tahap pencarian dan pembentukan jati diri. Ketika anak-anak di dalam keluarga mulai memasuki masa remaja, peran keluarga, atau orangtua sangatlah berperan penting sebagai sumber inspirasi dan tempat mendapatkan pelajaran karakter dan norma-norma yang berlaku dalam masyarakat.

Remaja merupakan masa transisi seorang anak menuju fase kedewasaan. Tidak semua remaja memiliki perilaku yang salah ketika dia berada pada suatu keluarga yang tidak harmonis (broken home), ada pula beberapa remaja yang dapat berpikiran positif ketika ia dihadapkan pada kondisi keluarganya yang tidak utuh sehingga pada akhirnya dapat melahirkan perilaku yang positif dalam kehidupannya sehari-hari. Perilaku anak-anak broken home cenderung berubah menjadi perilaku yang negatif, namun tidak semua remaja broken home mengalami perubahan seperti itu, ada juga beberapa remaja yang hidup dalam keluarga yang baik-baik atau harmonis, namun mereka memiliki perilaku yang negatif pula. Hal ini 
disebabkan oleh faktor lain di dalam keluarga tersebut seperti tidak adanya rasa empati dan penerimaan secara terbuka dari orangtua. Menurut penelitian Ramadhani (2013) proses komunikasi antara orangtua dan anak dalam menanamkan perilaku positif berlangsung secara tatap muka dan berjalan dua arah artinya ketika orangtua mengomunikasikan pesan-pesan yang berisi nilai-nilai positif yang akan memengaruhi perilaku anak ke arah yang positif, dalam menanamkan perilaku positif ada hal-hal yang dapat mendukung orangtua untuk memudahkannya menyampaikan pesan-pesan tentang nilainilai positif tersebut.

Alasan peneliti mengambil judul perilaku remaja broken home karena semakin maraknya kasus perceraian dan rumah tangga yang tidak harmonis yang dampaknya akan sangat berpengaruh pada perilaku remaja terutama di kota-kota besar.

Peran orangtua dalam melakukan komunikasi keluarga yang efektif dengan anak yang sedang tumbuh dalam kondisi keluarga yang tidak harmonis sangatlah penting.

Karena apabila orangtua tidak dapat melakukan komunikasi yang baik dengan anak yang sedang dalam kondisi keluarga broken home, maka ditakutkan sang anak akan memilih jalannya sendiri dengan memiliki pola pikir berbeda yang negatif sehingga menimbulkan perilaku yang negatif pula dan tidak heran apabila suatu hari anak yang akan lebih mudah melakukan hal-hal yang berhubungan dengan kenakalankenakalan remaja saat ini.

Penelitian yang dilakukan oleh Junaidi (2013) menunjukkan bahwa perilaku komunikasi yang terjadi antara orangtua dan anak mengenai prestasi belajar belum sepenuhnya berjalan secara efektif.

Hal ini disebabkan oleh intensitas komunikasi interpersonal orangtua dan anak masih kurang sehingga anak enggan terbuka mengenai prestasi belajar. Kurangnya dukungan, rasa empati, dan sikap positif yang diberikan orangtua kepada anak juga memengaruhi hubungan interpersonal orangtua dan anak sehingga dapat memengaruhi prestasi belajar. Dampak lain dari peran komunikasi keluarga terhadap perilaku remaja broken home ini adalah, orangtua akan lebih sulit dalam melakukan komunikasi yang efektif dengan anak yang sudah terlanjur berada pada garis negatif kehidupan remaja broken home sehingga orangtua pun akan sulit untuk mengarahkan perilaku anak tersebut pada hal-hal yang positif.

Orangtua saat ini hanya memberikan kebutuhan materi pada anaknya, sehingga mereka menjadi pribadi yang tidak lengkap. Hal ini dikarenakan kesibukan-kesibukan orangtua terutama pada keluarga yang tinggal di kota besar atau ketidaktahuan orangtua dalam mendidik anak.

Salah satunya contoh adalah kasus perceraian di Kota Pare-Pare. Angka perceraian di Kota Pare-Pare semakin hari semakin tinggi. Berdasarkan data yang terungkap di Pengadilan Agama Kota ParePare, jumlah perkara yang masuk pada tahun 2013 sebanyak 5.134 perkara. Sementara pada tahun 2014 jumlah perkara naik menjadi 5.684 perkara. Sedangkan perkara yang menyebabkan perceraian 2013 sebanyak 4.571, naik pada 2014 menjadi sebanyak 4.926 perkara.

Menurut catatan yang tertulis di Pengadilan Agama Kota Pare-Pare, tingginya tingkat perceraian di Kota Pare-Pare masih didominasi alasan ketidakharmonisan yang mencapai 114 perkara, suami tidak bertanggungjawab 92 perkara, adanya pihak ketiga 70 perkara, dan akibat kondisi ekonomi mencapai 54 perkara.

Dalam penelitian ini masalah yang akan diangkat adalah mengenai perubahan perilaku negatif seorang remaja yang hidup dalam suatu keluarga broken home, yakni bagaimana perilaku siswa di lingkungan keluarga? Permasalahan tersebut kemudian di break down menjadi: 1) Bagaimana perilaku komunikasi siswa yang broken home? 2) Faktor-faktor apakah yang menghambat perilaku komunikasi siswa broken home di SMK Negeri 3 Pare-Pare?

Manfaat penelitian yang diharapkan adalah untuk memberikan pemahaman kepada orangtua guru dalam melakukan 
hubungan komunikasi interpersonal dalam menghadapi siswa yang broken home.

\section{LANDASAN TEORI}

\section{Pengertian Komunikasi}

Komunikasi atau communication berasal dari bahasa latin communis yang berarti 'sama'. Communico, communication atau communicare yang berarti membuat sama (make to common). Secara sederhana komunikasi dapat terjadi apabila terdapat kesamaan makna mengenai suatu pesan yang disampaikan oleh pengirim pesan dan diterima oleh penerima pesan. Oleh sebab itu, komunikasi bergantung pada kemampuan seseorang untuk dapat memahami satu dengan yang lainya (communication depends on our ability to understand one another) (Darmawan, 2009). Jika tidak terjadi kesamaan makna antara kedua pelaku komunikasi, dengan kata lain si penerima pesan tidak mengerti apa yang disampaikan oleh pengirim pesan, maka komunikasi tidak terjadi. Dalam rumusan lain, situasi tidak komunikatif.

Menurut Kincaid dan Schramm dalam Tubbs \& Moss (2008) agar seseorang dapat berkomunikasi dengan efektif, seseorang dituntut tidak hanya memahami prosesnya, tetapi juga mampu menerapkan pengetahuan secara kreatif. Komunikasi yang efektif adalah komunikasi dalam mana makna yang distimulasikan serupa atau sama dengan yang dimaksudkan si pengirim pesan (komunikator). Pendeknya, komunikasi efektif adalah makna bersama. Harold D. Lasswell dalam Cangara (2007) mengatakan bahwa cara yang tepat untuk menerangkan suatu tindakan komunikasi adalah dengan menjawab pertanyaan "siapa yang menyampaikan, apa yang disampaikan, melalui saluran apa, kepada siapa dan apa pengaruhnya".

Sebuah definisi yang dibuat oleh kelompok sarjana komunikasi (Cangara, 2007) yang mengkhususkan diri pada studi komunikasi antarmanusia (human communication) mengatakan bahwa: "Komunikasi adalah suatu transaksi, proses simbolik yang menghendaki orang-orang mengatur lingkunganya dengan:

Membangun hubungan antar sesama manusia; (2) Melalui pertukaran informasi; (3) Untuk menguatkan sikap dan tingkah laku orang lain; serta (4) Berusaha mengubah sikap dan tingkah laku itu". Everett M. Rogers dalam Darwis (2007) seorang pakar Sosiologi Perdesaan Amerika yang telah banyak memberi perhatian pada studi riset komunikasi, khususnya dalam hal penyebaran informasi membuat definisi bahwa komunikasi adalah proses di mana suatu ide dialihkan dari sumber kepada suatu penerima atau lebih, dengan maksud untuk mengubah tingkah laku mereka. Dari pengertian komunikasi yang telah dikemukakan di atas, maka jelaslah bahwa komunikasi antarmanusia hanya bisa terjadi jika ada seseorang yang menyampaikan pesan kepada orang lain dengan tujuan tertentu, artinya komunikasi hanya bisa terjadi kalau didukung oleh adanya sumber pesan (komunikator), pesan (message), media (channel), penerima (komunikan), dan umpan balik (feedback). Kelima hal inilah yang kemudian disebut unsur-unsur komunikasi atau komponen komunikasi.

\section{Komunikasi Antarpribadi}

Komunikasi antarpribadi adalah satuan dasar komunikasi. Peristiwa komunikasi antar pribadi mencakup hampir semua komunikasi informal dan basa-basi, percakapan seharihari yang dilakukan sejak saat bangun pagi sampai kembali ke tempat tidur. Sebagian besar kegiatan komunikasi antarpribadi yang dilakukan berlangsung secara tatap muka (face to face). Oleh karena dilakukan secara tatap muka, maka terjadilah kontak pribadi (personal contact) antara komunikator dan komunikan. Pribadi komunikator menyentuh pribadi komunikannya. Ketika komunikator menyampaikan pesan, umpan balik berlangsung seketika.

Komunikator dapat mengetahui tanggapan komunikannya pada saat itu juga. Jika menurut persepsi komunikator reaksi komunikan menyenangkan atau tanggapanya positif, maka ini merupakan suatu pertanda bagi komunikator bahwa komunikasinya 
berhasil sehingga dapat melanjutkan komunikasinya dan tentu saja dapat mempertahankan gaya komunikasinya, sebaliknya apabila tanggapan komunikan negatif maka komunikator harus mengubah gaya komunikasinya sampai komunikasinya tersebut berhasil (Sukamadani, 2007).

Berdasarkan kenyataan tersebut, jenis komunikasi antarpribadi dipandang sebagai komunikasi yang paling efektif di antara bentuk komunikasi yang lain kerena efek umpan balik, aksi maupun reaksi verbal dan non verbal langsung terlihat antara komunikator dengan komunikan. Jarak partisipan yang dekat dan dilakukan dengan saling pengertian dapat mengembangkan komunikasi antarpribadi yang memuaskan kedua belah pihak.

Pandangan bahwa komunikasi mendefinisikan hubungan antarpribadi telah dikemukakan oleh Ruesch dan Beteson dalam Rakhmat (2003) pada tahun1950-an. Gagasan ini kemudian dipopulerkan di kalangan komunikasi oleh Watzlawick, Beavin, dan Jackson dengan buku mereka "Pragmatis of Human Communication". Mereka melahirkan istilah baru untuk menujukkan aspek hubungan dari pesan komunikasi ini yang disebut metakomunikasi.

Perlahan-lahan studi komunikasi antarpribadi bergeser dari isi pesan ke aspek relasional atau aspek hubungan antarpribadi. Gerald R. Miller dalam Rakhmat (2003) dalam kata pengantar yang dituliskan untuk buku Explorations in interpersonal communications menyatakan : Understanding the interpersonal communications procces demands an understandingof the symbiotic relationship between communication and relational development: communication influences relational development, and in turn (simultaneously), relational development influences the nature of communication between parties to the relationship.

Untuk memperjelas apakah suatu komunikasi merupakan komunikasi antarpribadi, maka Everett M. Rogers dalam Liliweri (2009) mengemukakan beberapa ciriciri komunikasi antarpribadi yang membedakanya dengan bentuk komunikasi yang lain.
Ciri-cirinya adalah: a)Arus pesan cenderung dua arah; b) Konteks komunikasinya terbuka; c) Tingkat umpan balik yang terjadi tinggi; d) Kemampuan mengatasi tingkat selektivitas yang tinggi; e) Kecepatan jangkauan terhadap audiens besar; f) Efek yang mungkin terjadi adalah perubahan sikap.

Komunikasi merupakan suatu proses sosial di mana individu-individu yang terlibat di dalamnya saling memengaruhi. Proses pengaruh-memengaruhi ini merupakan suatu proses yang bersifat psikologi dan karenanya juga merupakan permulaan ikatan psikologi antarmanusia yang memiliki suatu pribadi dan memberikan peluang bakal terbentuknya suatu kebersamaan dalam sekelompok yang tidak lain merupakan tanda adanya proses sosial.

Komunikasi antarpribadi bersifat dinamis yang melibatkan cara berpikir, perasaan, pendapat maupun harapan, dan aksi reaksinya.

Apabila seorang komunikator sudah cukup mengenal keadaan sosiologis dan psikologis komunikan maka dia dapat menyesuaikan pesan yang sesuai dengan kebutuhan komunikan. Devito (2008) dalam bukunya mengatakan bahwa keberhasilan dalam menyampaikan informasi sangatlah ditentukan oleh sifat dan mutu hubungan di antara pribadi yang terlibat dan mengandung lima kualitas umum yang dipertimbangkan yaitu: keterbukaan (openness), empati (empathy), sikap mendukung (supportiveness), sikap positif (positiveness), dan kesetaraan (equality).

1. Keterbukaan. Kualitas keterbukaan mengacu pada sedikitnya tiga aspek dari komunikasi antarpribadi. Pertama, komunikator antarpribadi yang efektif harus terbuka kepada orang yang diajaknya berinteraksi. Hal ini tidak berarti bahwa orang harus membuka semua riwayat tentang hidupnya namun harus ada kesediaan untuk mengungkapkan informasi yang biasanya disembunyikan, asalkan pengungkapan diri ini patut. Kedua, mengacu pada kesedian komunikator untuk berekasi secara jujur terhadap stimulus yang 
datang. Aspek ketiga menyangkut kepemilikan perasaan dan pikiran. Artinya terbuka adalah mengakui bahwa perasaan dan pikiran yang orang lontarkan adalah memang miliknya dan harus dipertanggungjawabkan.

2. Empati. Henry Backrack dalam Ernawan (2008) mendefinisikan empati sebagai kemampuan seseorang untuk mengetahui apa yang sedang dialami orang lain pada suatu saat tertentu, dari sudut pandang orang lain itu. Orang yang empatik mampu memahami motivasi dan pengalaman orang lain, perasaan, dan sikap mereka, serta harapan dan keinginan mereka di masa mendatang. Pengertian yang empatik ini akan membuat seseorang lebih mampu menyesuaikan komunikasinya.

3. Sikap mendukung. Hubungan antarpribadi yang efektif adalah hubungan di mana terdapat sikap mendukung (supportivess). Sikap mendukung ditandai dengan sikap (1) deskriptif, bukan evaluatif, (2) spontan, bukan strategik, dan (3) provisional, bukan sangat yakin (Nasution, 2009).

4. Sikap positif. Sikap positif dalam komunikasi antarpribadi ada dua cara yaitu: (1) menyatakan sikap positif dan (2) secara positif mendorong orang yang menjadi teman kita berinteraksi. Sikap positif mengacu pada sedikitnya dua aspek dari komunikasi antarpribadi. Pertama, komunikasi antar pribadi terbina jika orang memiliki sikap positif terhadap diri mereka sendiri. Kedua, perasaan positif untuk situasi komunikasi pada umumnya sangat penting untuk interaksi yang efektif. Dorongan positif umumnya berbentuk pujian atau penghargaan, dan terdiri atas perilaku yang biasanya diharapkan. Dorongan positif ini mendukung citra pribadi seseorang dan membuatnya merasa lebih baik.

5. Kesetaraan. Komunikasi antarpribadi akan lebih efektif bila suasananya setara. Artinya, harus ada pengakuan secara diam-diam bahwa kedua pihak samasama bernilai dan berharga, dan bahwa masing-masing pihak mempunyai sesuatu yang penting untuk disumbangkan.

\section{Perilaku Komunikasi}

Komunikasi merupakan hal penting dalam kehidupan manusia. Manusia dibesarkan dan dibentuk kepribadiannya melalui komunikasi.

Manusia berhubungan dengan sesamanya menggunakan komunikasi. Manusia beribadah menggunakan komunikasi. Dengan demikian, komunikasi merupakan hal yang tak terhindarkan dari kehidupan manusia. "We can not not communicate" demikian kata seorang pakar komunikasi (Adrian, 2008).

Komunikasi bergerak melibatkan unsur lingkungan sebagai wahana yang "mencipta" proses komunikasi itu berlangsung. Porter dan Samovar mengatakan alih-alih komunikasi merupakan matriks tindakantindakan sosial yang rumit dan saling berinteraksi, serta terjadi dalam suatu lingkungan sosial yang kompleks. Lingkungan sosial ini merefleksikan bagaimana orang hidup, dan berinteraksi dengan orang lain. Perilaku tersebut terjadi akibat adanya proses penyampaian pengetahuan suatu stimulus sampai ada penetuan sikap untuk bertindak atau tidak bertindak, dan hal ini dapat dilihat dengan menggunakan panca indera seperti yang dikemukakan oleh seorang ahli komunikasi yaitu Rogers dalam Cangara (2007) yaitu "komunikasi adalah proses di mana suatu ide dialihkan dari sumber kepada satu penerima atau lebih, dengan maksud untuk mengubah tingkah laku mereka".

Perilaku atau tingkah laku adalah kebiasaan bertindak yang menunjukkan tabiat seseorang yang terdiri dari pola-pola tingkah laku yang digunakan oleh individu dalam melakukan kegiatannya. Lebih jauh dikatakan bahwa perilaku itu terjadi karena adanya penyebab tingkah laku (stimulus), motivasi tingkah laku, dan tujuan tingkah laku. Pengertian perilaku komunikasi berdasarkan beberapa pengertian di atas dapat dinyatakan bahwa sebagai tindakan yang dilakukan seseorang untuk menciptakan dan menyampaikan informasi kepada orang lain 
dengan tujuan-tujuan tertentu melalui upayaupaya komunikasi baik itu komunikasi verbal maupun non verbal.

Perilaku komunikasi antara guru dan siswa adalah bagaimana guru menunjukkan perilaku komunikasinya terhadap siswa. Tentunya perilaku komunikasi yang positif sangat penting terhadap pembentukan kepribadian siswa serta memberikan pengaruh yang sangat besar dalam keberhasilan pendidikanya. Perilaku komunikasi siswa yang telah disebutkan di atas memiliki pengaruh psikologis yang besar terhadap kegiatan belajar. Dengan adanya perhatian dari guru, siswa akan lebih giat dan lebih bersemangat dalam belajar karena ia tahu bahwa bukan dirinya saja yang berkeinginan untuk maju, akan tetapi orangtuanya pun demikian. Sebab baik buruknya prestasi yang dicapai anak akan memberikan pengaruh kepadanya dan perkembangan pendidikan selanjutnya.

\section{Broken Home}

Broken home adalah kurangnya perhatian dari keluarga atau kurangnya kasih sayang dari orangtua sehingga membuat mental seorang anak menjadi frustasi, brutal dan susah diatur. Broken home sangat berpengaruh besar pada mental seorang pelajar hal inilah yang mengakibatkan seorang pelajar tidak mempunyai minat untuk berprestasi.

Broken home juga bisa merusak jiwa anak sehingga dalam sekolah mereka bersikap seenaknya saja, tidak disiplin di dalam kelas mereka selalu berbuat keonaran dan kerusuhan, hal ini dilakukan karena mereka cuma ingin cari simpati pada teman-teman mereka bahkan pada guru-guru mereka. Untuk menyikapi hal semacam ini perlu diberikan perhatian dan pengarahan yang lebih agar mereka sadar dan mau berprestasi (Sukarman, 2015).

Pada umumnya penyebab utama broken home ini adalah kesibukan kedua orangtua dalam mencari nafkah keluarga seperti halnya ayah laki-laki bekerja dan ibu menjadi wanita karier. Hal inilah yang menjadi dasar seorang tidak memiliki keseimbangan dalam menjalankan aktivitas sehari-hari dan malah sebaliknya akan merugikan anak itu sendiri, di kala pulang sekolah di rumah tidak ada orang yang bisa diajak berbagi dan berdiskusi, membuat anak mencari pelampiasan di luar rumah seperti bergaul dengan teman-temannya yang secara tidak langsung memberikan efek/pengaruh bagi perkembangan mental anak.

Oleh karena itu mereka berusaha untuk mendapatkan perhatian dari orang lain. Tetapi sayang, sebagian dari mereka melakukan cara yang salah misalnya: mencari perhatian guru dengan bertindak brutal di dalam kelas, bertindak aneh agar mendapat perhatian orang lain, dan lain-lain. Kalau sudah brutal otomatis bisa salah pergaulan. Lalu mereka mulai melirik yang namanya rokok. Awalnya hanya sekali hisap, lama-lama jadi berkalikali.

Kemudian setelah merokok, mereka mulai mencoba yang namanya narkoba. Penyebab broken home: terjadinya perceraian, ketidakdewasaan sikap orangtua yang berkelahi di depan anak-anak, tidak bertanggungjawabnya orangtua sehingga tidak memikirkan dampak dalam kehidupan anak anak mereka, jauh dari Tuhan, sehingga masalah masalah tidak diserahkan kepada Tuhan, kehilangan kehangatan di dalam keluarga antara orangtua dan anak.

\section{METODE PENELITIAN}

Penelitian ini menggunakan penelitian pendekatan kualitatif dengan melalui metode pengumpulan data sebagai berikut:

1. Studi literatur.

2. Wawancara mendalam dengan berbagai informan yang telah terpilih sebagai data induktif.

Menurut Poerwandari (2008) penelitian kualitatif adalah penelitian yang menghasilkan dan mengolah data yang sifatnya deskriptif, seperti transkripsi wawancara, catatan lapangan, gambar, foto rekaman video, dan lain-lain. Dalam penelitan kualitatif perlu menekankan pada pentingnya kedekatan dengan orang-orang dan situasi penelitian, agar peneliti memperoleh pemahaman jelas tentang realitas dan kondisi 
kehidupan nyata (Patton dalam Poerwandari 2008).

Teknik analisis data adalah upaya yang dilakukan dengan jalan bekerja dengan data, mengorganisasikan data, memilah-milahnya menjadi satuan yang dapat dikelola, menintesiskannya, mencari, dan menemukan apa yang penting dan apa yang dipelajari dan memutuskan apa yang dapat diceritakan kepada orang lain. Pada tahap ini data dikerjakan dan dimanfaatkan sedemikian rupa sampai berhasil menyimpulkan kebenarankebenaran yang dapat dipakai untuk menjawab pertanyaan atau persoalanpersoalan yang diajukan dalam penelitian. Adapun metode yang digunakan untuk mengelola data kualitatif adalah dengan menggunakan metode induktif. Informan dalam penelitian ini adalah siswa, guru, dan orangtua siswa yang kebetulan bersedia menjadi responden kunci pada penelitian ini. Pemilihan responden tersebut berdasarkan kriteria yang sudah ditentukan oleh peneliti yang diharapkan akan berkolerasi pada apa yang menjadi sasaran dan tujuan dari penelitian tersebut.

Pendekatan pada aspek sosial dan lingkungan masyrakat pada informan tersebut ikut memengaruhi objektivitas dan subjektivitas dalam menelaah dan mengompilasikan aspek pada sekolah dan rumah tangga sehingga akan menghasilkan data empiris yang sangat dibutuhkan oleh peneliti dalam mengelaborasi hasil penelitian berdasarkan metode penelitian yang peneliti gunakkan secara kualitatif. Pendekatan dengan metode kualitatif ini akan terlihat setelah dilaksanakan deskripsi pada setiap informan yang terpilih dan pada akhirnya akan menghasilkan sebuah narasi yang dibutuhkan dalam menarik sebuah simpulan ilmiah secara kolektif

Adapun informan yang terpilih berjumlah enam orang menurut kriteria yang telah ditetapkan dalam penelitian ini. Informan tersebut masing-masing mewakili pendidik, mewakili siswa, dan mewakili orangtua, dimana semua informan sangat relevan dengan tujuan penelitian ini. Adapun kriteria informan yang terpilih dalam penelitian ini adalah sebagai berikut:
1. Dra. Hj Sahrina selaku Guru BK di SMK 3 Pare-Pare yang bersedia memberikan keterangan kepada peneliti yang terkait dengan penelitian ini;

2. Dra. Ummi Farida selaku Wali kelas dua yang bersedia untuk memberikan keterangan terkait dengan penelitian ini;

3. Rany adalah salah satu siswa kelas dua broken home di SMK 3 Pare-Pare yang terpilih untuk diwawancara oleh peneliti secara mendalam.

4. Puput termasuk salah satu siswa kelas dua yang masuk dalam kategori broken home sekalipun dalam prestasi di sekolah cukup berprestasi

5. Arman adalah salah satu siswa kelas dua yang merupakan korban broken home sejak orangtuanya bercerai sejak dia masih di kelas tiga SMP

6. Suaib Rais, salah satu orangtua siswa Kelas dua SMK Negeri 3 Pare-Pare yang bersedia memberikan keterangan dan wawancara mendalam terkait dengan penelitian ini.

Data dari informan akan dianalisis dengan terlebih dahulu membuat kategorisasi dari data informan tersebut, dalam kategorisasi akan memudahkan untuk menganalisis dan menyimpulkan dari narasi para informan.

\section{HASIL PENELITIAN DAN PEMBAHASAN}

\section{Perilaku Komunikasi Antara Guru dan Siswa Broken Home}

Perilaku komunikasi antara guru dan siswa broken home dalam membantu perilaku belajar siswa adalah suatu komunikasi, baik verbal maupun non verbal yang dilakukan oleh guru dan siswa untuk memberikan motivasi, mendorong, perkembangan intelektual, emosional, dan sosial anak dalam meningkatkan perilaku belajarnya.

Perilaku komunikasi dianggap penting untuk diteliti karena tidak sedikit keluarga yang mengalami perpecahan. Perpecahan dalam keluarga dapat terjadi baik antara sesama orangtua, orangtua dengan anakanak.. Perpecahan orangtua itu dapat berujung 
pada perceraian. Dalam kenyataannya perceraian orangtua akan berpengaruh pada anak-anaknya. Anak-anak selalu menjadi korban atas perceraian orangtuanya. Akibat dari perceraian orangtua itu ada anak yang bisa tetap bangkit dan merasa tidak menjadikan beban hidup atas perceraian orangtuanya, namun tidak sedikit pula yang terpuruk atas perceraian orangtuanya. Anak yang terpuruk akibat perceraian orangtua sering menjadi anak yang broken home. Selain itu, secara prestasi, anak tidak dapat menunjukkan prestasi yang membanggakan dan terpengaruh dengan persoalan yang terjadi di tengah keluarganya.

Siswa yang dikatakan sebagai broken home pada dasarnya sehat secara fisik dan dalam kondisi kasat mata tidak ditemukan permasalahaan. Sementara yang dimaksud broken home adalah latar belakang situasi keluarga yang tidak kondusif bahkan cenderung mengarah pada permasalahan yang mengakar dan mengontaminasi segala aspek kehidupan dalam sebuah keluarga (Warsiman, 2007).

Hal yang demikian jelas sangat memengaruhi sisi psikologis anak, di mana akan dirasakan sebuah tekanan dan guncangan yang hebat dalam diri anak. Kesulitan belajar yang didasari oleh permasalahan keluarga broken home merupakan keadaan di mana siswa tidak dapat belajar sebagaimana mestinya.

Hal tersebut disebabkan adanya permasalahan yang bersifat intern dalam keluarga, yang kemudian berdampak pada permasalahan yang seperti tersebut di atas, dianggap tidak begitu mendasar dan terlihat sebagai permasalahan yang berasal dari luar diri peserta didik, sehingga ada sebuah kecenderungan pandangan bahwa hal tersebut hanya merupakan masalah personal yang terlalu dibesar-besarkan. Di sisi lain persoalan dalam keluarga atau rumah tangga kerap dianggap sebagai bentuk kegagalan dalam memenage sebuah perencanaan dalam hidup, sehingga timbul gejolak yang akan berujung pada berbagai macam permasalahan dan perpecahan.

Ada beberapa jenis kesulitan belajar yang dialami oleh menghinggapi siswa yang berlatar broken home, berdasarkan hasil penelitian antara lain adalah: kurangnya konsentrasi dalam mengikuti kegiatan belajar; Seringnya berulah/nakal/ribut didalam proses kegiatan belajar; Jatuhnya prestasi belajar secara signifikan; Labilnya kondisi emosional siswa di dalam keseharian dan dalam kegiatan belajar; Hilangnya mood atau keinginan yang memacu diri untuk belajar, adanya kecenderungan berperilaku menyendiri/mengasingkan dan tertutup terhadap orang lain, baik itu guru, siswa, dan orangtua.

Dari beberapa jenis kesulitan belajar di atas terlihat bahwa, pada kasus siswa yang berlatar broken home kesulitan belajar yang dialami bukan didasari oleh sisi kemampuan intelektualnya melainkan pengaruh lingkungan keluarga (extern) dan pada akhirnya berdampak pada penurunan prestasi akademik, perilaku, dan emosional.

Penulis melakukan penelitian di SMK Negeri 3 Pare-Pare selama kurang lebih dua bulan. Selama dua bulan tersebut penulis melakukan observasi dan wawancara terhadap salah satu wali kelas, guru BK, dan beberapa orang siswa.

Dari hasil wawancara tersebut penulis kemudian memilih tiga siswa yang dianggap layak dan memenulhi kriteria untuk dijadikan sebagai informan. Begitu pula halnya perilaku komunikasi yang terjadi di sekolah.

Untuk mengetahui bagaimana perilaku komunikasi siswa broken home di SMK 3 Pare-Pare, berikut ini adalah hasil wawancara dengan Dra. Hj Sahrina selaku Guru BK di SMK 3 Pare-Pare, beliau mengatakan bahwa teknologi informasi dan komunikasi telah berpengaruh terhadap perilaku komunikasi siswa di sekolah, terutama pola pikir dan perilaku siswa.

Hal ini dapat diamati melalui pola komunikasi dan penampilan siswa sehari-hari. Cara siswa berkomunikasi dengan teman, orangtua, dan guru sangatlah unik. Mereka menggunakan logat dan istilah yang kadangkadang sulit dimengerti oleh guru. Apalagi jika mereka menggunakan jejaring sosial seperti Facebook, Twitter, dan lain sebagainya. Beliau mengatakan, menghadapi siswa zaman sekarang berbeda dengan cara 
menghadapi siswa pada 20 atau 30 tahun yang lalu. Menghadapi siswa sekarang perlu pola komunikasi efektif antara pihak sekolah, orangtua, dan siswa itu sendiri" (Wawancara Hj. Sahrina Guru BP SMK Negeri 3 Makassar).

Lain halnya dengan pendapat Dra. Ummi Farida selaku Wali kelas, beliau berpendapat bahwa seorang guru pembimbing haruslah mempunyai tujuan dalam memberikan pola didiknya, hal ini agar para siswa bisa mengikuti setiap pelajaran yang diajarkan oleh guru kelasnya. Informan lebih menyesuaikan dengan anak dalam berkomunikasi, dengan mengenal tipe-tipe keperibadian anak seperti apa, maka sebagai guru pembimbing selalu melakukan pendekatan dan memberikan perhatian terhadap siswa yang bermasalah, baik masalah di kelas maupun masalah sikap siswa dalam bersosialisasi di lingkungan sekolah. Perlu melibatkan orangtua/ wali murid untuk membicarakan kondisi anak-anak saat berada di sekolah. Tanpa ada komunikasi yang terbuka dan lancar antara guru dan orangtua, sulit untuk mengubah perilaku anak-anak (Wawancara Ummi Farida Wali Kelas II SMK Negeri 3 Pare-Pare).

Sementara Rany salah satu siswa broken home di SMK 3 Pare-Pare mengatakan: "Saya kurang dapat berinisiatif dalam berkomunikasi baik di sekolah maupun di rumah, karena di rumah, saya dan orangtua jarang mempunyai waktu untuk bertemu dan berkomunikasi. Sehingga keadaan di rumah berpengaruh pada sifat dan perilaku saya saat di sekolah yang terbiasa menyendiri, karena itu saya tidak menyapa jika tidak terlebih dahulu disapa oleh guru atau teman. Kalau ada masalah, saya lebih banyak mengomunikasikannya dengan tante". Hasil wawancara di atas menunjukkan bahwa dapat berinisiatif dalam berkomunikasi, ia lebih banyak sharing masalah kepada tantenya dibandingkan orangtuanya sendiri karena kesibukan orangtua.

Hal yang sama juga dialami oleh Puput. Prestasi Puput di sekolah cukup baik, namun ia kerap mendapat teguran dari guruguru karena sering melamun pada saat pelajaran berlangsung, hal itulah memengaruhi perilaku belajar Puput di sekolah. Seperti dikatakan Puput: "Komunikasi di sekolah biasa-biasa saja, di sekolah saya hanya memiliki beberapa orang teman dekat yang selalu menemani, namun ketika di rumah saya merasa kesepian dan tidak punya siapa-siapa. Saya jarang sekali menghabiskan waktu di rumah, saya lebih sering bermain bersama teman-teman, bahkan saya lebih senang menginap di rumah teman dari pada di rumah sendiri. Semua itu saya lakukan semata-mata karena sulitnya merasakan kenyamanan dan kehangatan di dalam rumah sejak kedua orangtua saya bercerai".

Menurut keterangan salah seorang siswa Arman bawah orangtuanya telah bercerai sejak ia kelas tiga SMP. Sejak saat itu ia terbiasa melihat ayah dan ibu berseteru di depannya hampir setiap hari, setelah itu yang ia lakukan hanya mengurung diri di kamar. Jawaban yang serupa juga dikatakan oleh Arman siswa kelas dua SMK Negeri 3 Pare-Pare ini yang mengatakan bahwa: "Komunikasi yang terjadi di rumah maupun di sekolah terkesan cuek, "Saya jarang berkomunikasi dengan guru dan orangtua. Karena di sekolah saya dianggap anak yang nakal, malas, dan jarang masuk kelas ketika proses belajar berlangsung, saya lebih nyaman bergaul dengan teman-teman, di rumah orangtua saya sering berbicara kasar ataupun marah kepada saya, orangtua lebih mementingkan pekerjaan dibandingkan anaknya sendiri. Saya segan ataupun takut untuk membicarkan masalah di sekolah dengan orangtua. Saya lebih terbuka ke teman-teman dibandingkan ke orangtua sendiri.

Pada awal proses wawancara, Arman masih terkesan menutupi dan enggan untuk membagi cerita mengenai masalah keluarganya. Namun peneliti berusaha untuk bisa dekat dan terus berinteraksi dengannya. Suasana pun perlahan mulai mencair dan ia menunjukkan sikap yang positif dan terbuka. Dari jawaban yang diberikan informan di atas diketahui bahwa komunikasi yang terjalin di antara guru, orangtua, dan anak tidak terlalu intens karena orangtua sibuk dengan pekerjaannya. 
Komunikasi terjadi hanya pada saat orangtua maupun anak merasa ada kebutuhan yang harus dibicarakan dan sejauh itu komunikasi yang sehari-hari terjalin hanyalah komunikasi yang berada pada taraf komunikasi dangkal di mana komunikasi yang sesungguhnya tidak benar-benar terjadi "(Wawancara dengan Arman Siswa Kelas tiga SMK Negeri 3 Pare-Pare).

Seperti definisi komunikasi yang dibuat oleh kelompok sarjana komunikasi (Cangara (2007) yang mengkhususkan diri pada studi komunikasi antarmanusia (human communication) mengatakan bahwa komunikasi adalah suatu transaksi, proses simbolik yang menghendaki orang-orang mengatur lingkungannya dengan membangun hubungan antarsesama manusia; melalui pertukaran informasi; untuk menguatkan sikap dan tingkah laku orang lain; serta berusaha mengubah sikap dan tingkah laku itu.

Jadi komunikasi yang sebenarnya itu memiliki tujuan membangun hubungan antarsesama manusia, bertukar informasi, menguatkan sikap dan tingkah laku orang lain serta berusaha mengubahnya. Dari tiga pernyataan anak di atas menunjukkan bahwa sikap tertutup mereka didasari oleh sikap orangtua yang kurang perhatian terhadap masalah yang mereka hadapi. Orangtua kurang memiliki rasa empati dan dukungan kepada anak sehingga setiap masalah yang dihadapi seorang diri dan terkadang masalah di rumah dibawa ke sekolah sehingga mengganggu proses dan perilaku belajar di sekolah.

Konsep komunikasi antara siswa di sekolah dikemukakan oleh Napitupulu (2009) bahwa komunikasi sangat ditentukan perilaku dan tingkah laku seseorang dalam membangun komunikasi antara pihak pendidik dan siswa di kelas.

\section{Faktor-faktor yang Menghambat Perilaku Komunikasi Siswa Broken Home Di SMK Negeri 3 Pare-Pare.}

Perilaku komunikasi antara guru dan siswa tidak selamanya berlangsung secara efektif, karena ada hal atau faktor-faktor yang menghambatnya. Dari hasil penelitian ditemukan bahwa faktor-faktor yang menghambat komunikasi antara guru dan siswa di sekolah adalah seperti yang diutarakan oleh $\mathrm{Hj}$ Sahrina selaku Guru BK.

Adanya Ketidakterbukaan siswa terhadap guru BK, menurutnya ketidakterbukaan merupakan sikap di mana seseorang tidak mau mengungkapkan diri pada orang lain. Sebagai Guru BK tugas saya yaitu membimbing dan memberikan dorongan serta motivasi pada murid. Saya melihat bahwa ketidakterbukaan siswa terhadap guru BK disebabkan oleh adanya rasa takut dan rasa malu siswa dalam manceritakan masalah yang mereka hadapi.

Sedangkan menurut Ummi Farida selaku wali kelas faktor penghambat komunikasi antara guru dan siswa adalah: Bahasa, minat terhadap pelajaran, hambatan fisik, lingkungan, stereotip, dan sistem religi. Ummi Farida mengatakan, guru hendaknya memilih pola komunikasi yang tepat dan efektif dalam proses belajar mengajar khususnya dalam pendidikan yang berbasis multikultural. Agar antara guru dan siswa tercipta komunikasi yang aktif dan siswa tidak bosan untuk mengikuti pelajaran dengan baik, hingga tercipta persamaan persepsi berupa materi yang dapat dipahami dengan sempurna.

Konsep komunikasi yang perlu dibangun dalam proses belajar mengajar yang aktif antara siswa dan pendidik sehingga dalam interaksi dapat memberikan manfaat dalam proses pembelajaran (Warsiman, 2007).

Sama seperti penjelasan sebelumnya bahwa faktor yang menjadi penghambat Ummi Farida dalam berkomunikasi dengan siswa mengenai perilaku belajar siswa adalah ketidakterbukaan siswa dan kurangnya minat belajar siswa. Sadar akan hal itu beliau memilih pola komunikasi yang tepat dan efektif dalam proses belajar mengajar khususnya dalam pendidikan yang berbasis multikultural. Hal serupa juga dikemukakan oleh Rany salah satu siswa broken home di SMK 3 Pare-Pare mengatakan bahwa hambatannya berkomunikasi dengan orangtua dan guru seperti yang dikatakan oleh Rany: "Orangtua saya jarang berada di rumah, ia 
lebih sibuk bekerja. Kadang kalau ada masalah di sekolah saya lebih banyak mengomunikasikanya dengan tante sedangkan di sekolah saya enggan menceritakan masalah saya lebih memilih memendam masalah yang saya hadapi" (Wawancara Rany Siswa Kelas dua SMK Negeri 3 Makassar).

Sementara menurut Puput, karena ia merasa kesepian, seperti yang dikemukakan oleh Puput: "Yang menjadi hambatan ketika saya ingin berkomunikasi dengan orangtua mengenai sekolah, yaitu di rumah, saya merasa kesepian dan tidak punya siapa-siapa. Semenjak orangtua bercerai saya sulit merasakan kenyamanan dan kehagatan di rumah. Ibu biasa marah-marah kalau diajak berbicara mengenai masalah sekolah ketika ia sedang sibuk sehingga saya pun jadi takut mengungkapkannya".

Informan yang ketiga yaitu Arman memiliki pernyataan yang berbeda pula. Berikut ungkapan Arman: "Yang menghambat komunikasi orangtua dan anak di antaranya yaitu orangtua yang kurang bisa membagi waktu antara pekerjaan dan memberikan perhatian kepada anak di rumah sehingga komunikasi dengan anak tidak berjalan dengan lancar. Dan orangtua saya sering berbicara kasar ataupun marah kepada saya sehingga saya tidak terbuka kepada orangtua" (Wawancara Puput Siswa Kelas dua SMK Negeri 3 Pare-Pare).

Dari pernyataan informan di atas jelaslah bahwa faktor utama yang menghambat komunikasi antara orangtua, guru, dan siswa adalah intensitas interaksi yang kurang di antara orangtua dan anak sehingga anak pun enggan dan menutup diri dari orangtua dan guru, bahkan tidak jarang anak merasa takut akan respon yang diberikan orangtua terhadap peryataan atau keluhan mereka.

Hasil penelitian dari ketiga siswa broken home di SMK 3 Pare-Pare di atas diketahui bahwa faktor penghambat utama perilaku komunikasi yang terjadi antara orangtua, guru, dan siswa di sekolah adalah intensitas pertemuan yang kurang antara orangtua dan anak karena kesibukan orangtua bekerja. Kurangnya keterbukaan siswa terhadap guru dalam menceritakan masalah yang mereka hadapi, selain itu kurangnya dukungan, rasa empati, dan sikap positif dari orangtua yang menjadi faktor yang kedua yang menghambat perilaku komunikasi siswa broken home di sekolah.

Berdasarkan hasil penelitian yang diperoleh, maka dalam pembahasan ini akan menguraikan dan menganalisis secara rinci sesuai dengan teori yang penulis gunakan dihubungkan dengan perilaku komunikasi siswa broken home dengan menggunakan metode deskriptif kualitatif agar rumusan masalah dapat terjawab.

a. Keterbukaan

Berikut ini adalah hasil wawancara dari ketiga siswa broken home tentang keterbukaan mereka mengenai masalah perilaku komunikasi di sekolah.

Ketiga informan memiliki kesamaan dalam mengomunikasikan masalah perilaku komunikasi dan perilaku belajar. Mereka mengatakan bahwa mereka jarang berkomunikasi dengan orangtua karena orangtua mereka sibuk. Mereka juga kurang terbuka mengomunikasikan masalah sekolah kepada orangtua karena katakutannya terhadap respon orangtua yang negatif.

Keterbukaan dalam komunikasi antara orangtua, guru, dan anak merupakan modal dalam memahami masalah yang dihadapi oleh anak. Dengan adanya keterbukaan maka orangtua dan guru dapat mengetahui dan membantu menyelesaikan masalah yang dihadapi anak, dengan keterbukaan pula orangtua dan guru dapat mengembangkan segala potensi yang ada pada diri anak sehingga mampu untuk berprestasi. Komunikasi yang efektif tidak mungkin terjadi bila para pelakunya tidak terbuka dan kurang percaya satu sama lain.

Seperti yang dikemukakan oleh salah satu orangtua siswa: "Selama ini sebagai orangtua kami terlalu sibuk dengan tugas kantor, di mana baik istri saya maupun saya sendiri terkadang saya kurang menanyakan kepada anak saya tentang kegiatannya di sekolah. Memang nilai yang diperoleh disekolah cukup menurun, karena saya kurang memberikan perhatian" (Wawancara 
dengan Suaib Rais orangtua siswa Kelas dua SMK Negeri 3 Pare-Pare).

Hasil wawancara di atas, menunjukkan bahwa adanya kesadaran orangtua terhadap komunikasi dengan anaknya sehingga kurang mampu membina hubungan yang baik melalui komunikasi yang intensif dan diwarnai suasana santai dengan saling berbagi, saling mendengarkan, dan mengungkapkan isi hati, maka komunikasi yang terbuka pun dapat terjalin. Sebaliknya jika orangtua tidak mampu mempertahankan kesinambungan komunikasi yang intensif dengan anak, maka perilaku komunikasi pun dapat terhambat.

b. Empati

Menurut Henry Backrack dalam Devito (2008) empati adalah kemampuan seseorang untuk mengetahui apa yang sedang dialami orang lain pada suatu saat tertentu, dari sudut pandang orang lain itu. Dari hasil penelitian yang diperoleh disimpulkan bahwa empati dari Guru BK dan wali kelas terhadap siswa broken home ditunjukkan dengan cara mendampingi dan berusaha mendengarkan keluhan siswa sehingga setiap masalah yang dihadapi anak di rumah dapat diselesaikan.

\section{c. Sikap Mendukung}

Sikap mendukung yang dimaksudkan oleh Devito (2008) adalah hubungan yang ditandai dengan sikap deskriptif, bukan evaluatif, spontan, bukan strategik, dan provisional, bukan sangat yakin. Hubungan komunikasi yang efektif ditandai dengan adanya pemberian dukungan. Apabila siswa merasa mengalami masalah, di sinilah guru BK memberi dukungan bagi siswa tersebut agar lebih terbuka dalam membicarakan masalahnya.

\section{d. Sikap Positif}

Sikap positif yang dimaksudkan Devito (2008) adalah menyatakan sikap positif dan secara positif mendorong orang yang menjadi teman untuk berinteraksi.

Sikap positif mengacu pada sedikitnya dua aspek dari komunikasi antarpribadi. Pertama, komunikasi antarpribadi terbina jika orang memiliki sikap positif terhadap diri mereka sendiri. Kedua, perasaan positif untuk situasi komunikasi pada umumnya sangat penting untuk interaksi yang efektif.
Dengan adanya rasa positif dari kedua belah pihak yaitu guru dan siswa maka akan memunculkan suasana positif maka akan tercipata suasana nyaman untuk berkonsultasi.

e. Kesetaraan

Menurut Devito (2008), komunikasi antarpribadi akan lebih efektif bila suasananya setara. Artinya, harus ada pengakuan secara diam-diam bahwa kedua pihak sama-sama bernilai dan berharga, dan bahwa masing-masing pihak mempunyai sesuatu yang penting untuk disumbangkan menyangkut pentingnya pesan orangtua kepada anak dan begitu pula sebaliknya.

Dari hasil penelitian diperoleh hasil bahwa belum tercipta kesetaraan di antara orangtua, dan anak. Orangtua terlalu sibuk dengan pekerjaannya sehingga terkadang mengenyampingkan masalah yang dihadapi anak padahal seharusnya orangtua memperhatikan anak sebagai subjek yang perlu dibimbing serta dibina dengan kasih sayang bukan hanya melihatnya sebagai objek semata yang diasuh secara otoriter mengikuti kemauan orangtua.

Masalah pribadi serta kesibukan orangtua membuat anak merasa diabaikan dan tidak diperhatikan sehingga komunikasi di antara orangtua dan anak tidak berjalan secara efektif.

\section{PENUTUP}

\section{Simpulan}

Perilaku komunikasi siswa broken home di sekolah belum sepenuhnya efektif. Hal ini disebabkan oleh:

Perubahan perilaku negatif seorang siswa yang hidup dalam suatu keluarga broken home, yakni perilaku siswa di lingkungan keluarga adalah komunikasi antara orangtua dan siswa kurang terjalin dengan baik. Karena siswa merasa orangtua kurang memberikan perhatian terhadap siswa yang menyebabkan siswa sibuk dengan urusannya sendiri dan kurang memperhatikan proses belajar mengajar di sekolaah.

Faktor-faktor yang menghambat perilaku komunikasi siswa broken home di 
SMK Negeri 3 Pare-Pare bahwa faktor penghambat utama perilaku komunikasi yang terjadi antara orangtua, guru, dan siswa di sekolah adalah intensitas pertemuan yang kurang antara orangtua dan anak karena kesibukan orangtua bekerja. Kurangnya keterbukaan siswa terhadap guru dalam menceritakan masalah yang mereka hadapi, selain itu kurangnya dukungan, rasa empati, dan sikap positif dari orangtua yang menjadi faktor yang kedua yang menghambat perilaku komunikasi siswa broken home di sekolah.

\section{Saran}

Perlunya ada tindakan yang lebih aktif dari pihak guru membangun komunikasi dengan siswa yang broken home sehingga siswa yang kurang mendapat perhatian dari orangtua akan lebih aktif mengikuti proses belajar di kelas.

\section{DAFTAR PUSTAKA}

Adrian (2008) Berkomunikasi dalam Keluarga. Surabaya, Pradipta Utama.

Cangara, H. (2007) Pengantar Ilmu Komunikasi. Jakarta, PT. Raja Grafindo Persada.

Darwis (2007) Konsep Komunikasi yang Efektif. Jakarta, PT. Rajawali Press.

Devito, J.A. (2008) Ilmu Komunikasi dalam Organisasi. Jakarta, Ghalia Indonesia.

Ernawan, H. (2008) Pendekatan Sosiologi dalam Berkomunikasi. Jakarta, Rosdakarya.

Junaidi (2013) Pengaruh Komunikasi Interpersonal Orangtua dan Anak dalam Meningkatkan Prestasi Belajar Anak di SMAN 4 Samarinda Seberang. eJournal Ilmu Komunikasi. 1 (1), 442-455.

Liliweri (2009) Ilmu dan Teori Berkomunikasi yang Baik. Jakarta, Rajawali Perss.

Napitupulu, D. (2009) Komunikasi dan Psikologi Komunikasi. Jakarta, Panembahan.

Nasution (2009) Masalah dan Solusi dalam Berkomunikasi. Jakarta, Mandar Maju.

Poerwandari (2008) Metode Penelitian Kualitatif. Jakarta, Gramedia.

Rahmadi (2006) Konsep dan Teori Komunikasi dalam Berperilaku. Jakarta, Grasindo Utama.

Rakhmat, J. (2003) Psikologi Komunikasi. Bandung, Remaja Rosdakarya.
Ramadhani, R. (2013) Komunikasi Interpersonal Orang Tua dan Anak dalam Membentuk Perilaku Positif Anak pada Murid SDIT Cordova Samarinda. eJournal Ilmu Komunikasi. 1 (3), 112-121.

Sukamadani (2007) Perilaku dalam Berkomunikasi. Jakarta, Panembahan.

Sukarman (2015) Psikologi Anak dan Remaja. Jakarta, Rosdakarya.

Tubbs, S.L. \& Moss, S. (2008) Pendekatan Komunikasi dalam Keluarga. Jakarta, Panembahan.

Warsiman (2007) Konteks Komunikasi dan Interaksi Dalam Keluarga. Jakarta, Mandar Maju. 